\title{
Problems Faced by Students in Writing English Academic Summary
}

\author{
Atika Kumal Dewi ${ }^{1}$, Nanda Saputra ${ }^{2}$ \\ ${ }^{1}$ English Education Department of Islamic State Institute of Kediri (IAIN Kediri), Jl. Sunan Ampel \\ No.7 Ngronggo Kediri, East Java, Indonesia. Email: atikakumala@gmail.com \\ 2 Sekolah Tinggi Al-Hilal Sigli, Aceh, Jln .Lingkar Keunire - Pidie-Aceh, Indonesia. Email: \\ nandasaputra680@gmail.com
}

\begin{tabular}{|c|c|}
\hline Artic & Abstract \\
\hline $\begin{array}{l}\text { tory: } \\
25 \text { February } 2021\end{array}$ & $\begin{array}{l}\text { Purpose: This research investigates the problems faced by college students in } \\
\text { writing English academic summary. }\end{array}$ \\
\hline & Methodology/Approach/Design: The method used includes surface strategy \\
\hline Acc & $\begin{array}{l}\text { taxonomy by Heidi Dulay and non-linguistic problem using personal } \\
\text { interview. The data were collected from } 35 \text { original summary writing }\end{array}$ \\
\hline Key & documents for the linguistic sources and Zoom meeting video recorder for the \\
\hline $\begin{array}{l}\text { Linguistic problems, } \\
\text { non-linguistic problems, } \\
\text { surface strategy taxonomy, } \\
\text { English academic summary } \\
\text { writing. }\end{array}$ & $\begin{array}{l}\text { non-linguistic sources. The samples were } 7 \text { students in } 5 \text { th semester of } \\
\text { English Education Department, Islamic State Institute of Kediri. To gather } \\
\text { data, the researchers employed a random sampling technique. The data } \\
\text { analysis used descriptive qualitative methods. } \\
\text { Results: The result of the data analysis shows that the students committed } \\
\text { four types of surface strategy taxonomy: omission, addition, misformation, }\end{array}$ \\
\hline & and miss ordering. Misformation is the type of common problem found in the \\
\hline Res & $\begin{array}{l}\text { students' summary writing. In the personal interview, it was found that } \\
\text { misunderstands about advanced-vocabulary is the common non-linguistic }\end{array}$ \\
\hline & $\begin{array}{l}\text { problem. These represent the problems faced by students. } \\
\text { Practical Implications: This research study has implications for teachers and }\end{array}$ \\
\hline Atika & $\begin{array}{l}\text { students. The results can be of use for improving students' writing and } \\
\text { designing alternative teaching skills for this important skill. }\end{array}$ \\
\hline $\begin{array}{l}\text { Email: } \\
\text { atikakumala@gmail.com }\end{array}$ & $\begin{array}{l}\text { Originality/Value: Summary writing process helps the students to expand } \\
\text { their view about proper academic writing. This situation suggests that } \\
\text { summary writing is a good strategy technique to be applied in college } \\
\text { students. However, the ability in writing an academic summary using surface } \\
\text { strategy taxonomy needs to be improved. }\end{array}$ \\
\hline
\end{tabular}

\section{Introduction}

Writing for the English Education Department of Indonesian students is one of the most difficult aspects of developing English proficiency in college due to the fact that English is not a native language in Indonesia. Thus, writing an English scholarly review serves as a demonstration of their writing ability. A summary is a concise summary of a text's key points. At some point during their classes, the students would almost definitely be assigned to summarize a particular letter, a task for the primary intention of summarizing. At times, often they use summaries in more holistic contexts, integrating them into more nuanced pieces of writing alongside quotes, paraphrases, and their thoughts. They most certainly summarize for a number of reasons, both outside of school and during their tenure as a student. 
According to Janice R. Matthews and Robert W. Matthews, scientific writing can be defined narrowly as the reporting of original research in journals or more broadly to encompass other ways that scientists share research information with one another, such as review articles, posters, and slide-based presentations (Jenice \& Robert, 2008). Jennifer Peat stated that scientific writing is about using words correctly and finding a precise way to explain what has done, what has found, and why it matters (Jennifer, 2002).The primary aim of scientific writing is not only about how good the presentation of information and thought is but rather its actual communication to the readers. It does not matter how pleased a research might be to have changed all the right data into sentences and paragraphs. How the readers can accurately comprehend what the research had in mind is the only matter (George \& Judith, 1990).

Additionally, they probably find it beneficial to summarize content based on the lecturer's suggestion letter, such as posts, plays, videos, seminars, tales, or presentations. The most succinct explanation suits on a single page. In essence, the aim of writing a review is to demonstrate students' comprehension of the major points of an assigned reading or watching, and therefore their teacher likely asks them to recap in order to ensure they comprehended the content. In addition, they outline a part of the whole of a source where the concepts included in the source are critical to the assignment on which they are employed and they believe they should be included. In contrast, they will take up an inordinate amount of space in their original configuration. They often do so where the general concepts found in a source are critical to integrating into their work. The elements contained in the same section as those core ideas, on the other hand, are not sufficient to prove the case. Summarizing English texts is also an effective way to ensure that students comprehend a text by testing their ability to outline the key concepts. They most likely have a firm grip on the facts presented. For these purposes, it is important to examine the difficulties students encounter while composing an English academic review. This can be beneficial for teachers, lecturers, and others involved in the study and academic area of English as a reference for boarding English learning and research.

Numerous linguistic scholars have discussed their ideas about literature. The ideas are strikingly similar. Trudy Wallace, Winifred E. Stariha, and Herbert J. Walberg propose one explanation that writing is the culmination of many distinct actions that are extremely difficult to learn concurrently. Note-taking, describing a core theme, outlining, drafting, and editing are only a few of these distinct acts.(Wallace, Stariha, \& Walberg, 2004). Meanwhile, Gordon Rohman stated that Writing is best defined as a phase, something that undergoes constant change over time, similar to organic development (Christina, 2002). H. Douglas Brown has clarified another hypothesis. He further pointed out that written items are often the culmination of processes such as reasoning, copying, and revising that involve advanced skills that not every speaker instinctively possesses (McDonald \& et al, 2002).

Additional contexts for English as Foreign Language students' writing difficulties had grown. Yemeni students of English as a Foreign Language considered mistakes and errors in their writing abilities as a result of the conventional approaches and procedures used by writing 
teachers at Sana'a University (Al-Jaro, Al-Quiadhi, \& Ramadhan, 2016). Their research discovered that students struggled with coherence and continuity as a result of a lack of reading, first language transfer, and insufficient writing practice. Additionally, the Iraqi English as Foreign Language students' writing composition difficulties and errors in grammar, punctuation, spelling, and handwriting were exposed (Nasser, 2019).

Concerning the above-mentioned writing problem, it is true that writing is the most difficult ability for students to master, since it requires not only the generation of ideas but also their translation into perceived text(Richards \& Renandya, 2002)and necessitates the integration of neurological, emotional, cognitive, and affective competencies(Murray \& Moore, 2006). It found two reasons why English as a foreign language students struggled with writing. The first factor was their poor English writing proficiency, while the second factor was their insufficient consistency in learning the writing skills (Husin \& Nurbayani, 2017). As a result, they became dissatisfied with their writing ability.

A Summary is a condensed version of a text that expresses the text's central ideas by recorded expression which is related to paraphrasing. It must be shorter than the original text, contain the text's core concept, and, where appropriate, use the recorded expression. This study concentrated on four critical techniques: reading each paragraph at least twice to grasp the main idea; creating an outline before writing a summary; using one's vocabulary to prevent plagiarism, and comparing the summary writing to the original document to avoid confusion.

Using the example above, the researchers examined the students' writing mistakes by having them create informative text. The researchers' objective is to determine the most common types of errors committed by students. The researchers conducted an error analysis of students' descriptive text writing using the Surface Strategy Taxonomy. They had learned English literature in Senior High School, focusing on descriptive texts. The researcher assessed the mistakes in this analysis using the surface strategy taxonomy. This category of errors is inextricably linked to one another. The researcher then classified the errors using the surface strategy taxonomy, which holds considerable promise for researchers interested in understanding the neural mechanisms underlying the learner's reconstruction of the new language. Thus, students need to consider the different forms of writing errors to gain a good understanding of writing abilities.

\section{Methodology and Procedures}

This study is a qualitative employing a descriptive design. The participants of this research were7 students of fifth semester of Islamic State Institute of Kediri (IAIN Kediri) in the academic year of 2020/2021, in the Quantitative Research Methodology course. The instruments of this research were the students' academic summary writing documents as the linguistic sources and Zoom Meeting Conference recorder as the non-linguistic sources during conducting the interview.

\section{Results and Discussion}


The instrument used in this research is documents formed in soft file (Microsoft Word). In addition, the researcher collected students' papers in writing English academic summary during conducting Quantitative Research Methodology course in the $5^{\text {th }}$ academic year 2020-202I. Data collection took three stages, first the researcher collected English academic summary writing made by students, second the researcher analyzed the grammatical errors made by the students as evidence of the linguistic problem which the student were facing during the writing process. In addition, the researcher used Surface Strategy Taxonomy. After that, the researcher conducted personal interview with each student to figure out their non-linguistic problems they were facing.

\section{Types of Linguistic Problems}

As stated previously, the results were grouped around the two research questions. First, it presented the findings of the linguistic problems faced by students in writing English academic summary on Quantitative Research Methodology course during 1 semester in the $5^{\text {th }}$ semester of English Education Department. Therefore, the analysis of the writing English academic summary errors' made by students is by using surface strategy taxonomy proposed by Heidi Dulay and to diagnose the linguistic problems. The total errors committed by the students were 853 items which were spread out into 4 types (omission, addition, misformation, missordering)

\section{Surface Strategy Taxonomy}

The data derived from students' summary writing documents showed that there were different amount of linguistic problems happening in each documents. The total number and percentage of each type are figured out as follows:

Table 1 Students' Linguistic Problem in Writing English Academic Summary on Surface Strategy Taxonomy

\begin{tabular}{|l|l|l|l|}
\hline No & Types of Linguistic Problems & Total & Percentage \\
\hline 1. & Omission & 142 & $16.65 \%$ \\
\hline 2. & Addition & 96 & $11.25 \%$ \\
\hline 3. & Misformation & 537 & $62.95 \%$ \\
\hline 4. & Misordering & 78 & $9.15 \%$ \\
\hline Total & 853 & $100 \%$ \\
\hline
\end{tabular}

Table 1 inferred that misformation is the highest among the types, reaching 537 items of linguistic problem or $(62.95 \%)$. However, the number of linguistic problem in omission amounts to 142 items (16.65\%), the addition is 96 items $(11.25 \%)$, and the misordering is only 78 items $(9.15 \%)$. The finding is based on surface strategy taxonomy which misformation is the most linguistic problem is made by the students in writing English academic summary.

Type of Linguistic Problems is The Most Repeatedly Performed by the Students 
This section discusses the second question, which is the most frequently encountered form of linguistic problem among students. The researcher assessed the type of linguistic complexity based on the number of students who completed the assignment. Then, the various categories of linguistic problems are addressed in terms of their frequency and percentage depending on the surface strategy taxonomy.

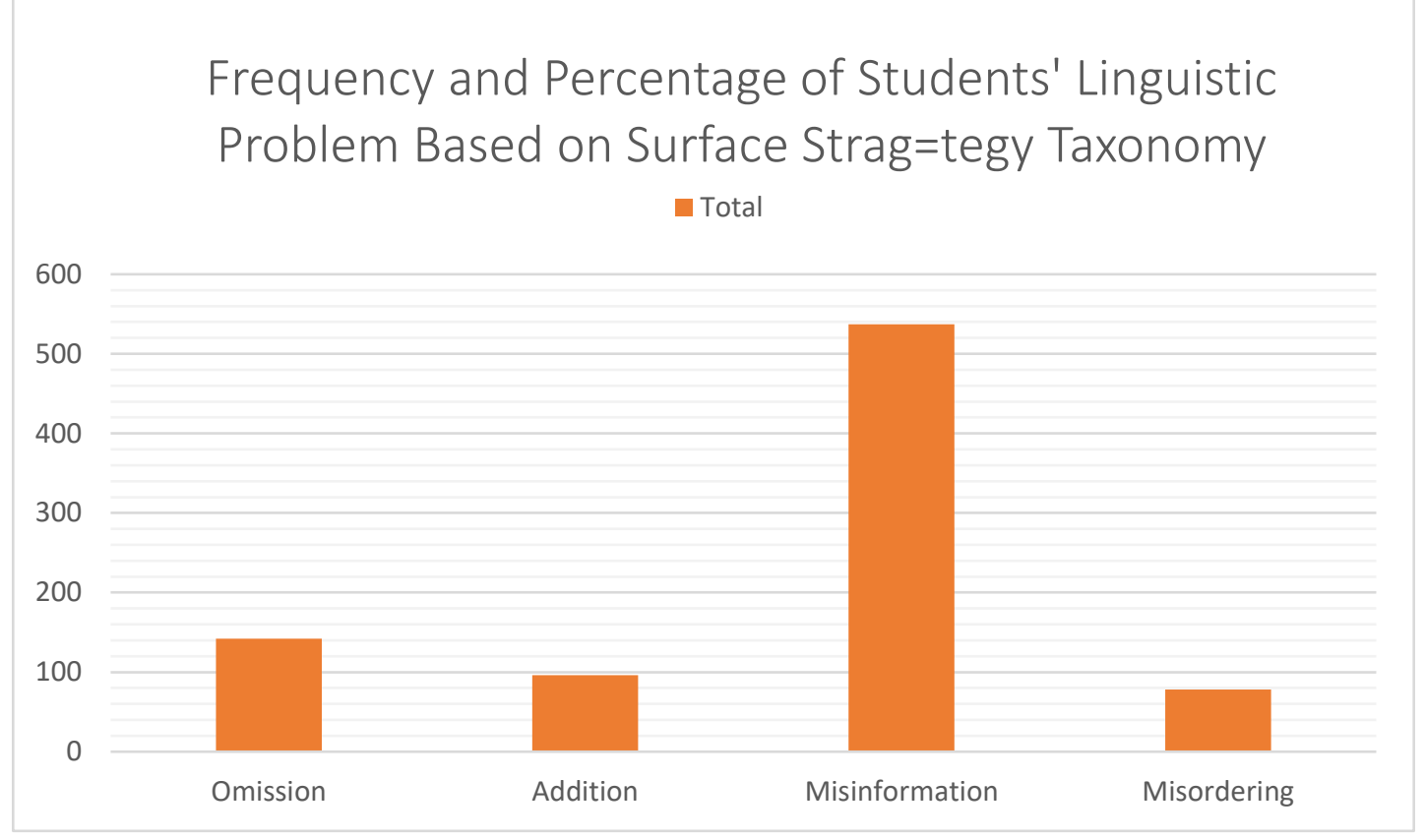

Chart 1: Frequency and Percentage of Students' Linguistic Problem Based on Surface Strategy Txonomy

The diagram shows that the total linguistic problem performed in the students' summary writing is 853 items. It represents that the highest frequency of linguistic problem based on surface strategy taxonomy is misinformation which performs 537 items or $73.46 \%$. Most students decay to construct sentences in present tense using proper grammatical patterns. They repeatedly write inappropriate verbs. The most second linguistic problems is an omission by accumulating 142or 16.82\%. Besides the misformation, the students write linguistic problem in part of speech, such as the different function of made and make in their sentence, or when they construct disconnected words as like adding-s/es after a noun to indicate plurals. The third type of linguistic problem is the addition accumulating of 96 items or $11.35 \%$. In this case, most students' made linguistic problems in parts of speech, like when they added simple verb or past participle verb in their sentences even though the sentences need verbs other than to be plus past participle verb. Misordering is the type of linguistic error with the lowest frequency, it only calculates 78 items or $8.46 \%$.

\section{Type of Non-Linguistic Problem}

The results on the students' linguistic problems based on Surface Strategy Taxonomy above, the researcher conducted and triangulated to the personal interview with each of them. The reseacher constructed their non-linguistic problem become one as shown below: 
A. In the process of writing an academic summary, their responses are:

Student 1 Reading books that the lecturer recommended, going to the library, writing a summary.

Student 2 Reading the lecturer's instruction, reading books that the lecture recommended, finding other books for strengthening the idea, writing summary.

Student 3 Going to the library, reading books that the lecturer recommended, finding other books in the library, constructing the idea, writing summary.

Student 4 Reading books that the lecturer recommended, going to the library, writing a summary.

Student 5 Reading books that the lecturer recommended, going to the library, writing a summary.

Student 6 Reading books that the lecturer recommended, going to the library, writing a summary.

Students 7 Going to the library, reading books that the lecturer recommended, finding other books in the library, constructing the idea, writing summary.

B. The total of books they read before writing summary, their responses are:

Student $1 \quad 2$ books

Student $2 \quad 4$ books

Student $3 \quad 3$ books

Student $4 \quad 2$ books

Student $5 \quad 2$ books

Student $6 \quad 2$ books

Student $7 \quad 4$ books

C. The most difficult thing when they write their summary, their responses are:

Student $1 \quad$ Advanced-vocabulary

Student 2 Understading

Student 3 Constructing the idea

Student 4 Grammatical understanding

Student 5 Grammatical Understanding 
Student $6 \quad$ Motivating Atmosphere (Friendship Circle)

Student $7 \quad$ Understanding

D. The reason for the difficulty, their responses are:

Student 1 Because on online learning, I cannot catch up exactly what my lecturer explained and I never practice my English that's why my English is never getting advanced

Student 2 I cannot understand in 2 books that my lecturer recommended before writing summary, that's why I read 4 books to boost up my understanding

Student $3 \quad$ I have a problem in creating idea so I always find writing a summary difficult in constructing the idea

Student 4 I have a poor understanding of grammatical pattern

Student 5 I have a poor understanding of grammatical pattern

Student 6 My friendship circle doesn't come from English student

Student 7 I have poor understanding of the grammatical pattern so I often misunderstand in translating before I write the summary

E. The students' opinion son summary writing as a primary assignment are as follows

Student $1 \quad$ Writing summary helps me to learn the lecture material and guides me to construct the best final project which is writing thesis proposal. So I recommend for all lecturer to apply writing summary as a primary assignment before conducting the final project written in an academic text.

Student 2 First, writing a summary is difficult for me. However, at the end of the course in this lecture I find easy to create a thesis proposal for my final project examination

Student 3 I think writing summary is the best technique in teaching college student, because everyone here is learning by doing and analyzing.

Student 4 In the online era of teaching, writing summary assignment guides me self to learn what I am poor in. I learn so much new academic vocabulary.

Student 5 I have problem with the grammatical pattern. By doing this assignment, I learn to read a lot and automatically to analyze a lot. It is training for me. I can have a better understanding of grammatical pattern after passing this course

Student $6 \quad$ I think everyone is helped by being given this kind of assignment. So, this teaching technique is good to be applied

Student 7 I find so many new books to strengthen my summary. 
In conclusion, the students' reasons for encountering the non-linguistic problems of writing English academic summaries can be identified into two. The first is the limitation of grammatical knowledge in the aspects of academic writing such as vocabulary, organization, understanding, reading recommended books, grammar, and mechanic. The second point is about personal reasons, including lack of reading books, friendly atmosphere, and the frequency of writing. On the other hand, they argue that writing summary is the best method to be applied in teaching technique. Because of summarizing, they can automatically learn new vocabulary and proper structure in constructing an academic writing.

\section{Discussion}

Based on the result of the research, problems faced by students in writing English academic summary can be classified into two categories: linguistic problem which can be analyzed through the classification of surface strategy taxonomy (omission, addition, misinformation, and missordering), and non-linguistic problem which can be analyzed through personal interview with each of the students. Explicitly, the highest frequency of linguistic problem in writing English academic summary is misformation which consists of 537 error items or $63.37 \%$, followed by omission which consists of 142 error items or $16.82 \%$, then addition is 96 error items or $11.35 \%$ and the last is misordering which consists of 8.46 error items or $8.46 \%$.

As shown in the research result above, it can be inferred that the students got linguistic problems analyzed by Surface Strategy Taxonomy in 4 types, namely omission, addition, misinformation and misordering. From the analysis, the researcher found that the most linguistic problem that student repeatedly fixed was misinformation. The analysis ex[lained that the students were also able to resolve non-linguistic issues by personal interviews, such as a lack of understanding of grammatical patterns, terminology, syntax, and mechanics. In terms of the material problem, it is linked to difficulties in researching and creating pertinent concepts, which require object comparisons; as a result, the essay's thesis is often unknowable. In terms of the arrangement, the mistakes are based on sentence form, a lack of transformation phrases, inconsistencies in the composition of whole-to-whole, similaritiesto-differences, and point-by-point structures, an unstated subject sentence for each body paragraph, undeveloped supporting concepts, and repetition of ideas/words in the concluding paragraph of the article. Another issue students face when it comes to language is choosing the right words and registers for the circumstance and meaning of their essay. Meanwhile, students' compare and contrast essays often include errors in subject-verb agreement, tenses, pronouns, auxiliary verbs, plural forms, and -s/-es and -ed forms. Finally, mechanics concerns errors in punctuation, capitalization, and pronunciation.

\section{Conclusion and Suggestion}

In the line with the research of problems faced by students in writing English academic summaries, there are two categories of problems faced by students. First, the most students fixed linguistic problem represented in the analysis found all error types of surface strategy taxonomy which is the omission, addition, misformation and misordering. Second, the 
students fixed with non-linguistic problem analyzed by a personal interview with each of them. The percentage of linguistic problems (ranked according to the type of error object that appeared most frequently) that resulted from students' English summary writing based on surface strategy taxonomy that is the omission of verb that consist of 537 or $63.37 \%$, the second is an addition that consists of 142 or $16.82 \%$, then the third is misformation that consists of 96error item or $11.35 \%$, and the last is misordering that consists of 78 or $8.46 \%$. it can be concluded that the highest frequency of linguistic problem is misfomation which consistsof 537 erre item or $63.37 \%$ and the lowest is omission which consists of 78 error items or $8.46 \%$. On the other hand, the researcher found that the most non-linguistic problem of the students in writing English academic summary was lack of proper grammatical pattern knowledge to construct a good summary. However, all the sample students were helped by giving the kind of summary writing as one of the teaching technique in a college life, because they feel during the process of writing, they found many new views, such as advanced vocabulary, books, and training writing skill. In addition, writing an English academic summary is one of the best methods in teaching strategy applied in college life, because it can stimulate the students to read and to write more appropriately. However, summary writing technique also needs to be improved more for both the students and the lecturer.

\section{Conflict of Interest}

The authors declare no conflict of interest

\section{Funding}

The authors conducted this study at his own expense and was not funded by any institution/ university.

\section{Availability of Data and Material}

The data that support the findings of this study are available from the corresponding author, upon reasonable request.

\section{References}

Al-Jaro, M. S., Al-Quiadhi, A. M., \& Ramadhan, K. Y. (2016). The Effect of Prewriting Techniques on Yemeni EFL Tertiary Learners' Writing Skills. Academic Journal, 112-126.

Christina, R. M. (2002). Teaching Writing. USA: Southern Illinois University Press.

George, D. G., \& Judith, A. S. (1990). "The Science of Scitific Writing" in The American Scientist, Vol. 78. 1. 
Husin, M. S., \& Nurbayani, E. (2017). The Ability of Indonesian EFL Learners in Writing Academic Papers. Dinamika Ilmu, 237-250.

Jenice, R. M., \& Robert, W. M. (2008). third edition. In Succesful Scientific Writing (p. 1). USA: Chambridge University Press.

Jennifer, P. e. (2002). In Scientific Writing Easy When You Know How (p. x). London: BMJ Publishing Group.

McDonald, C. R., \& et al. (2002). Teaching Writing. USA: Southern Illinois University Press.

Murray, R., \& Moore, S. (2006). The Handbook of Academic Writing. New York: Open University Press.

Nasser, S. M. (2019). Iraqi EFL Students' Difficulties in Writing Composition: An Experimental Study. International Journal of English Linguistics, 9(1), 178-184.

Richards, J. C., \& Renandya, W. (2002). Methodology in Language Teaching: An Anthology of Current Practice. New York: Chambridge University Press.

Wallace, T., Stariha, W. E., \& Walberg, H. j. (2004). Teaching Speaking, Listening and Writing. International Academy of Education \& International Bereau of Education, (p. 15). Chicago.

Waway, B. J. (2013). An Analysis of Grammartical Errors in Writing Recount Text Based on Surface Strategy Taxonomy at The First Year of SMA YP UNILA Bandrlampung. Unpublised Scipt: Universitas Bandar Lampung. 